\title{
Adapting Mentorship across the Professions: A Fijian View
}

\author{
Donasiano Ruru, Fiji National University. \\ Kabini Sanga Faculty of Education, Victoria University, Wellington, NZ. \\ Keith Walker University of Saskatchewan, Canada. \\ Edwin Ralph, University of Saskatchewan, Canada.
}

Contact Email: edwin.ralph@usask.ca

\begin{abstract}
This paper describes three mentorship workshops facilitated in Fiji, which were part of 11 such sessions recently conducted throughout the Pacific island region. The authors investigated the findings that emerged in these three workshops as part of an ongoing leadership initiative co-sponsored and cofunded by five institutions: Leadership Pacific, the Pacific Co-operation Foundation, the Social Sciences and Humanities Research Council of Canada, the University of Saskatchewan, the University of the South Pacific, and Victoria University of Wellington. Workshop attendees represented a variety of professions and occupations from educational, health care, government, and religious organizations. The researchers achieved their purpose by facilitating the three cohorts of Fijian leaders to begin to develop an adaptive mentorship approach that resonated with the attendees. The authors also extracted findings that could inform future research investigating how leaders representing different cultures and professions could adapt a generic mentorship model to create unique frameworks with the potential to enhance mentoring practice in their respective situations.
\end{abstract}

Key Words: Inter-professional Mentorship; Cross-disciplinary Research; International Collaboration; Cultures in Coaching; Fiji.

\section{Introduction}

Interest has expanded worldwide regarding the role of mentorship within professional and organizational life (Allen \& Eby, 2007; Clutterbuck, Poulsen, \& Kochan, 2012) and within the leadership-development process (Rombeau, Goldberg \& Loveland-Jones, 2010; Wheeler, Keller, \& Dubois, 2010). Leaders across the disciplines and from many nations have shown a growing interest in the process of mentorship and coaching (Carnegie, 2011; Gundling, Hogan, \& Cvitkovich, 2011; Hutchings, Huber, \& Ciccone, 2011), as demonstrated by a corresponding increase in related research, publications, websites, and conferences over the past three decades (Chun, Sosik, \& Yun, 2012; Emelo, 2011; International Coach Federation, 2012). For instance, at the time of writing, we conducted a preliminary online search for available books related to the topics of mentoring and coaching, and found 5,480 titles from a variety of disciplines. Our analysis showed a category-breakdown among

The current issue and full text archive of this journal is available at http://www.business.brookes.ac.uk/research/areas/coachingandmentoring/ 
these titles that showed: $40 \%$ of the publications were related to generic or popularized themes of mentoring/coaching; 25\% referred to mentorship in educational contexts (i.e., college, university, school, or other training contexts); $20 \%$ connected to business/industry; $10 \%$ related to women and youth; and $5 \%$ to real-world narratives and biographies of mentors.

The overall purpose of the research we report in this article was to investigate how a crossdisciplinary cohort of educational and professional leaders from Fiji examined one adaptive mentorship model in order to clarify their conceptualization of "effective mentorship" within the Fijian context. The venue for this activity was a series of three workshops that we, the four workshop leaders, recently conducted at three locations on the largest island, Viti Levu. We facilitated attendees' clarification of the essence, the principles, and the practice of effective mentoring across the professions in Fijian society, and thereby invited them to consider how a specific mentoring model, Adaptive Mentorship (Ralph \& Walker, 2011a, 2011b, 2012a) might help inform that task.

\section{Research Questions}

We posed the following questions derived from the purpose of the study, which we used to help guide the research:

1. To what extent did the workshops accomplish their objectives?

2. What was the attendees' emerging view of effective mentorship in the Fijian context?

3. How did their preliminary conceptualizations compare to other views of mentorship?

\section{Literature Review}

Although definitions of "mentoring" and "coaching" in the literature and in the field, have varied considerably, many authors conceptualize the former as being less structured and longer in duration than the latter (Bozeman \& Feeney, 2007; Brefi Group, 2011; Haggard, Dougherty, Turban, \& Wilbanks, 2011; Koortzen \& Oosthuizen, 2010). We agree with scholars (Brock, 2011; Chu, 2009; Clutterbuck, 2008; Rose Ragins \& Kram, 2007; Willens, 2012) who see the two processes as sharing common characteristics, such as: (a) they involve providing support to help both individuals in a mentorship dyad develop personally and socially/professionally; (b) they have functioned in family, community, and organizational settings across the ages; (c) they are practiced both formally and informally in a variety of forms; (d) they can yield potential benefits and drawbacks for all stakeholders; and (e) they are influenced by a variety of contextual factors and conditions, not the least of which is the quality of interpersonal relationships forged between/among the mentoring/coaching participants (Bachkirova, Jackson, \& Clutterbuck, 2011; Bozeman \& Feeney, 2007; Yoo, 2004).

Educators and researchers across the professional disciplines have recognized the benefits of mentorship and coaching programs (Chang, Munoz, Donoff, Kinnunen, \& Wright, 2012; Coates, 2012; Stanulis, Little, \& Wibbens, 2012), as well as their limitations, such as: (a) a scarcity of practical mentoring models to guide practice (Abedin, Biskup, Silet, Garbutt, Kroenke, \& Feldman et al., 2012; Ralph \& Walker, 2011a); (b) a need for mentorship personnel to be trained in applying the models (Chrosniak, Walker, \& Ralph, in press; Schreuder, Wolswijk, Zweemer, Schijven, \& Verheijen, 2012; Wasburn, Wasburn-Moses, \& Davis, 2012; and (c) an obligation to enhance the entire mentorship process through ongoing research and development (Sambunjak, Straus, \& Marusic, 2006; Ward \& Wu, 2012).

The current issue and full text archive of this journal is available at http://www.business.brookes.ac.uk/research/areas/coachingandmentoring/ 
Earlier research that typically focused on mentorship and coaching within specific organizations and nations (Allen \& Eby, 2007) has more recently expanded to include a broader examination of such topics as global leadership development (Grundling, Hogan, \& Cvitkovich, 2011), inter-professional mentorship (Sanga \& Chu, 2009), and cross-cultural coaching (Outer den, 2010). There is growing interest in such topics as mentorship practiced by multi-cultural teams in cross-disciplinary and interprofessional settings (Passmore, 2009; Ralph \& Walker, 2011a).

With respect to mentoring/coaching practice in the South Pacific island nations, there is little comprehensive research literature related to actual mentorship processes (EEO Trust, 2011). The available documentation is scant and piecemeal, and focused on local situations (Wheeler \& Leftwich, 2012); however, a growing desire to enhance the processes of leadership and mentorship is emerging across the entire region (Leadership Pacific, 2005; Sanga \& Chu, 2009).

Furthermore, our synthesis of this limited body of research has revealed three key points about mentorship in the Pacific region:

1. There is evidence of the generic qualities of effective mentorship that have been previously identified in the broader international literature (Allen \& Eby, 2007; Rose Ragins \& Kram, 2007), whereby it is characterized as a positive dyadic relationship that facilitates mutual development of protégé and mentor, alike (Dunphy et al., 2008);

2. It reflects the pervasive impact of political and economic factors that influence organizational and institutional decision-making, especially in developing countries that have experienced colonial, post-colonial, and neo-colonial pressures in their histories (Firth, 2006; Fullan, 2007; Lawson, 2010; Madraiwiwi, 2006).

3. It is unique from mentorship practiced in other jurisdictions, in that it emphasizes not only the Pacific culture and environment, as well as the influence of family, church, community traditions, and Pacific metaphors, which all affect residents' thinking, in general, and mentoring practice, in particular (EEO Trust, 2011; Lawson 2010; Mara \& Marsters, 2009; Wheeler \& Leftwich, 2012).

The research-findings regarding the Adaptive Mentorship model (originally called Contextual Supervision by its creators, Ralph and Walker, who were the two Canadian members of our research team) showed that: (a) AM was a cross-disciplinary, developmental model they refined over the past two decades for application in a variety of mentoring/coaching/supervisory contexts; (b) it focused on mentors adapting their mentoring response to match their protégés' existing developmental needs; and (c) it has been shown to help mentoring dyads not only clarify their conceptualization of the entire mentorship process, but to guide their practice within their respective mentorship roles and responsibilities (Ralph, 1998a, 2005; Ralph \& Walker, 2010, 2011a, 2011b, 2011c, 2012a). Ralph and Walker's most current AM research has solicited evaluations of the model by 47 "panels of experts" (i.e., recognized researchers and practitioners reputed to be knowledgeable in a certain area, as described by Fereday \& Muir-Cochrane, 2006; Keeney, Hasson, \& Mckenna, 2006; Rolfe, 2006). The panels of experts attended recent AM presentations/workshops conducted by members of our researchteam in eight countries. Our preliminary analysis of the written assessment-comments voluntarily and anonymously submitted by 555 of these experts revealed that AM is consistently judged as a valuable conceptual guide for mentorship, but that to be most efficacious, AM's potential users must be trained in its application/adaptation (Ralph \& Walker, 2013). We describe the AM model in Figure 1.

The current issue and full text archive of this journal is available at http://www.business.brookes.ac.uk/research/areas/coachingandmentoring/ 
Figure 1. The Adaptive Mentorship model.

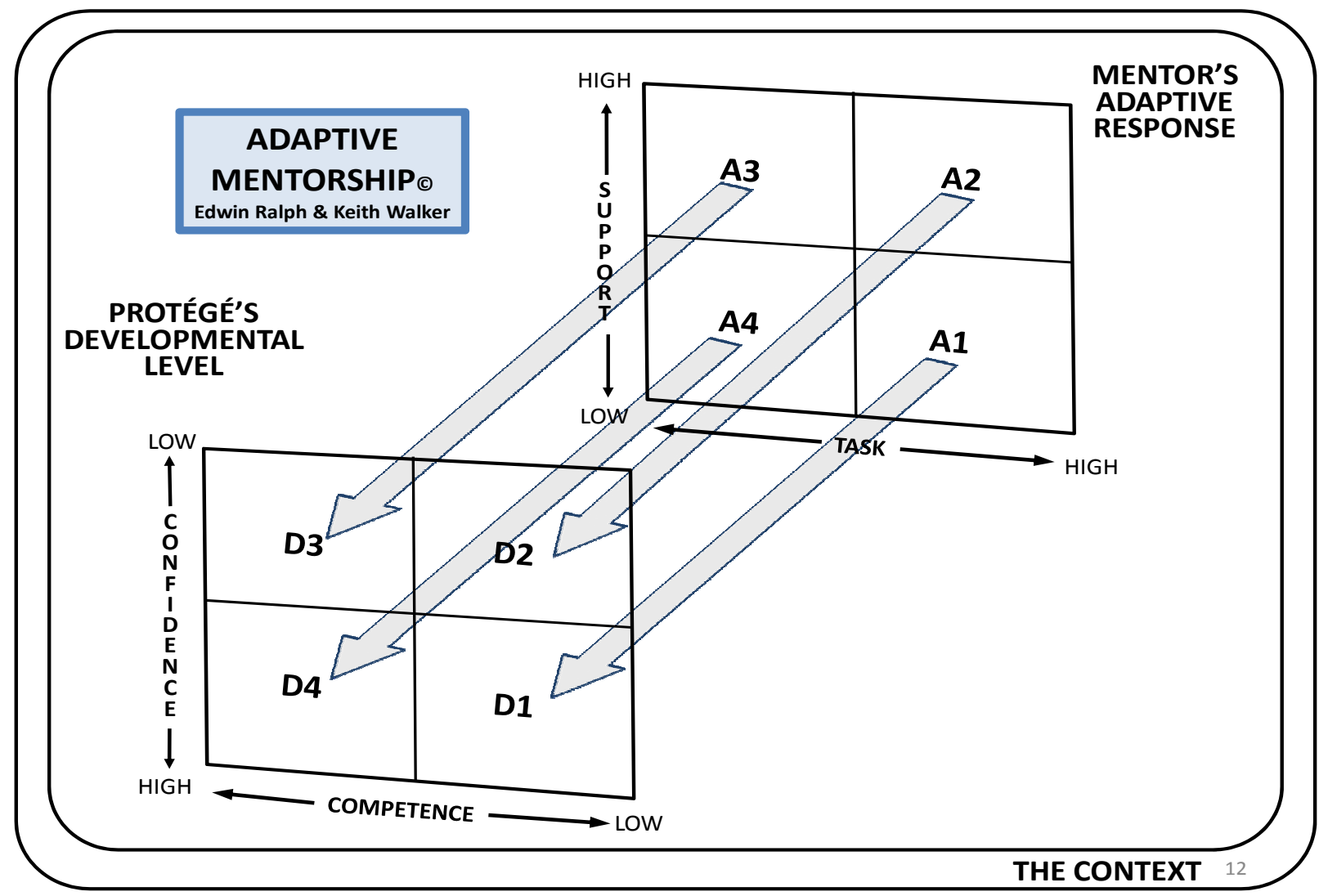

Each large arrow represents a mentor's response reflecting his/her specific position on the A-grid. By means of this A-response, the mentor is adapting his/her mentoring behavior to match the protégé's existing developmental level on the D-grid for a particular skill-set being practiced. Thus, the mentor will match A1 with D1, A2 with D2, and so forth. The degree of a mentor's support (i.e., amount of psycho-emotional encouragement and bolstering) will be inversely proportional to the protégé's level of confidence in the particular skill. Similarly, the extent of the mentor's task response (i.e., amount of technical direction given to the protégé) will be inversely proportional to the level of the protégé's actual competence in performing the task in question.

Figure 1 depicts $\mathrm{AM}$ as two facing windows, with the A-grid representing mentors' adaptive response to the protégés' existing level of development for each skill set being learned. Within the model, mentors modify their mentorship response, which consists of two dimensions: (a) the task aspect (i.e., the degree of specific direction given to the protégé regarding the technical, mechanical, or procedural aspect of the latter's performance of the particular task); and (b) the support dimension (i.e., the degree of psychological/social/emotional encouragement mentors provide the protégés practicing that specific skill-set). The D-grid represents the protégé's task-specific developmental level, and consists of two dimensions: the protégé's competence level (i.e., the actual technical ability to perform

The current issue and full text archive of this journal is available at http://www.business.brookes.ac.uk/research/areas/coachingandmentoring/ 
the skill-set in question), and his/her confidence level (i.e., the degree of their self-assurance, composure, psychological comfort, security, and sense of safety in performing it).

The heart of the AM model is represented by the shaded arrows linking the D- and A-grids, which portray the mentor's matching of one of four typical "A" (adaptive) responses matched with a similarly numbered " $\mathrm{D}$ " (developmental) level characterizing the protégé's performance of the particular task/competency. Obviously, there are many more combinations than these four possibilities, but the key principle is that the mentor's response will vary in inverse proportions to the protégé's D-level, For instance, a protégé's high competence level (the base of the D4 quadrant) requires a low task response by the mentor (the base of the A4 quadrant), because the protégé is already skilled in that task. Similarly, the protégé's D4 high-confidence level would require a lower support response from the mentor, as designated in the A4 quadrant, because the protégé's then-existing elevated confidence would not need the mentor's bolstering. In fact, our research has shown that when the mentor mismatches the amount of support and task required by the protégé, the latter's frustration and resentment will increase (Ralph, 1998a, 2005). However, mentorship dyads who systematically apply the AM model have been able to (a) clarify their conceptualization of the overall mentoring process; (b) understand how to adjust their respective mentorship roles; and (c) recognize and defuse potential interpersonal conflicts arising in the mentoring process (Ralph \& Walker, 2010, 2011a, 2012b).

\section{The South Pacific Context}

During the past three decades, educational and professional leaders from several Pacific island nations have been engaged in reform initiatives to reduce or eradicate earlier colonial and post-colonial structures from their respective societies and institutions (Hooper, 2005; Lawson, 2010; Thaman, 2006). They have sought reforms in the operation of their respective governments, in the administration of financial aid by donors, and in the enhancement of their educational and business systems (Puamau, 2005; Ruru, 2009; Sanga, 2005, 2009). These reform efforts, which in turn had implications for mentorship practice, have been based on fundamental social principles embraced by many leaders throughout the Pacific island region (Sanga, Tagivakatini \& Johansson-Fua, 2008; Thaman, 2009).

These principles are that: (a) decisions concerning local educational and social policy should be made by the people from each locale; (b) personhood in these initiatives should be understood as being relational in nature more than being individualistic; (c) reform processes should be framed according to utilitarian, experiential, emotional, and subjective perspectives that focus on individuals' cyclical or divergent thinking, rather than according to "outside" viewpoints that typically focus on abstract, theoretical, cognitive, or objective aspects that stress linear or convergent thinking; and (d) research regarding Pacific development issues should de-emphasize reliance on Westernized and colonial/postcolonial paradigms, but should favour using Pacific paradigms in Pacific contexts with Pacific languages, cultures, and values.

A specific example illustrating this Pacific focus on leadership and mentorship was the establishment of a new initiative called Leadership Pacific in 2005 (Leadership Pacific, 2005). Leadership Pacific can be characterized less as a formal organization and more as a movement or program made up of clusters of educators, professionals, and students within each island nation who represent a variety of educational institutions, government departments, agencies, and organizations. A key goal of Leadership Pacific is to assist young college and university students from the South Pacific islands to develop into ethical leaders, who in turn will be committed to help enhance the development

The current issue and full text archive of this journal is available at http://www.business.brookes.ac.uk/research/areas/coachingandmentoring/ 
of their own environments, local institutions, communities, and nations, and then eventually the world. The motto of Leadership Pacific is "1,000 New Generation Pacific leaders by 2015.”

Leadership Pacific (LP) was initiated by one of our research team-members, Professor Kabini Sanga, a Solomon Islander, who is currently on faculty at Victoria University of Wellington, New Zealand. LP was originally funded by the New Zealand International Aid and Development Agency (NZAID), but is now supported on an activity basis by interested institutions/organizations, who request the establishment of the LP program in their institution or community. LP was a product of the original Rethinking Pacific Education Initiative for Pacific People by Pacific People (RPEIPP) that operated from 2001 to 2006. A major characteristic of these programs is that they were established and managed by Pacific island people, with government and donor agencies playing a supportive but less directive role. These programs were successful in facilitating collaboration among leaders from a complex web of professional networks representing a variety of local, national, and regional organizations across Micronesia, Melanesia, and Polynesia. Moreover, this work was accomplished with minimal dependency on political, administrative, and/or donor backing.

Because of the importance relegated to the process of mentorship within leadership-development, LP initiated a series of 2011 mentorship workshops in four Pacific island nations (i.e., Cook Islands, Fiji, Tonga, and New Zealand) with the purpose of assisting participants to re-examine the concept of mentorship and to enhance its practice in their respective countries. Taking into consideration LP's vision, as well as the research results supporting effective professional development (e.g., Schleicher, 2009), our leadership team planned the series of workshops described in this article to enhance each cohort's effective mentorship practice in their respective settings.

\section{The Fijian Context}

Fiji is a chain of 322 islands, the two largest of which are inhabited by $70 \%$ of Fiji's 855,000 people. The majority of the population inhabit the cities of Lautoka, Nadi, and Suva on the largest island (United States, 2012). Fiji is unique among its Pacific neighbours in that approximately 57\% of its population is indigenous and $37 \%$ is Indo-Fijian, the latter being descendants either of: (a) indentured labourers brought from India by British landowners to work in the sugar cane fields during the late 1800s and early 1900; or (b) large numbers of immigrants arriving from India during the 1920s and 1930s (Nabobo-baba, 2009; Ramesh, 2010). Over time the indigenous citizens tended to be employed in government and military occupations, and the Indo-Fijians tended to become the business and commercial class (Hannan, 2006; Veitayaki, 2005). Religious affiliation in Fiji similarly reflected this trend: $52 \%$ of the population is Christian (largely Methodists and Roman Catholics); 33\% is Hindu, and 7\% is Muslim (BBC News, 2006, 2011). One of the main issues of contention in Fiji has been land tenure. Indigenous Fijian communities identify themselves with their land; and today approximately $90 \%$ of the land is held by Indigenous Fijians. The land cannot be sold and is held in trust by the government on behalf of the landowning units. On the other hand, Indo-Fijians produce more than $75 \%$ of the sugar crop but, in most cases, they must lease the land they use from its ethnic Fijian owners. This land controversy has also influenced the social and political life of the country (Naidu, 2006); but like the other island-nations across the Pacific, Fiji has been seeking democratic, economic, educational, and social reform during the past several decades (BBC News, 2006, 2011; Norton, 2005; Selby \& Walsh-Tapiata, 2005).

The current issue and full text archive of this journal is available at http://www.business.brookes.ac.uk/research/areas/coachingandmentoring/

International Journal of Evidence Based Coaching and Mentoring Vol. 11, No. 2, August 2013 
Fiji has experienced political turmoil during the past 40 years that stemmed from the rivalries between the Ethnic-Fijian and Indo-Fijian populations (Ramesh, 2010). In 1970 Fiji became an independent nation governed by a parliamentary democracy within the Commonwealth. However, it endured four coups between 1987 and 2006 and witnessed such volatile incidents as: abrogation and redrafting of its Constitution; expulsion from and readmission to the Commonwealth; removal and reinstatement of heads of state; and dissolution and re-formation of parliaments and/or interim governments.

Fiji's current military head, Commodore Frank Bainimarama, seized power in the December, 2006 coup and became interim prime minister, declaring a temporary military government (Fraenkel \& Firth, 2007). The coup was widely condemned by regional partners, including Australia, New Zealand, the United States, and the European Union (United States, 2012). However, even though Bainimarama promised to eliminate government corruption, establish election reform, and improve governance procedures, some observers have claimed that little progress has been made, and that his interim government is committing human rights violations (Colvin \& Francis, 2011).

Recently, however, several leaders of Pacific island countries have reaffirmed that Bainimarama's promised changes are gradually being enacted (Narayan, 2011); and these leaders are expecting the Fiji Government to remain true to its commitment to soon conduct free and fair elections (Chaudhary, 2011a, 2011b). The Pacific leaders further stated that Fiji’s Strategic Framework for Change is a credible plan that can position Fiji as a modern democratic nation. Furthermore, after showing little progress toward democratization, constitutional dialogue, or election preparation, the Fijian government in late 2011 and early 2012 did confirm that it was progressing toward holding elections. However, it also began implementing new policies that will further strengthen the regime's hold on society and security (United States, 2012).

\section{Methodological Considerations}

\section{Participants}

The attendees at the three workshops represented universities/colleges, government ministries, private businesses, international aid agencies, and church/religious organizations. The workshops were part of an ongoing leadership initiative co-sponsored by eight organizations: the Fiji National University, the University of the South Pacific, the Pacific Cooperation Foundation, Leadership Pacific, Victoria University of Wellington (New Zealand), the University of Saskatchewan (Canada), and the Social Sciences and Humanities Research Council of Canada.

Thirty-five individuals comprised a cross-disciplinary cohort who attended Workshop 1 that was of one-and-a-half days' duration and conducted on the Lautaoka campus of Fiji National University. The attendees were sectoral leaders in education, university academics, school administrators, and teachers spanning the pre-K to high school levels. Workshop 2 was smaller both in terms of duration (three hours) and size (eight attendees). It was convened at the campus of Corpus Christie Teachers College in Suva, and was attended by teacher educators who were faculty-members at the College. Workshop 3 was held at a hotel in Suva, and the cohort consisted of 22 delegates, who were administrators, regional civil servants, and graduate interns.

The current issue and full text archive of this journal is available at http://www.business.brookes.ac.uk/research/areas/coachingandmentoring/

International Journal of Evidence Based Coaching and Mentoring Vol. 11, No. 2, August 2013 
The two Pacific workshop organizers of our team had previously identified all attendees as being reputed leaders or experts in their respective professions (Wiersma \& Jurs, 2008), and who had also indicated their prior interest in enhancing the existing mentorship programs in their units. All of these individuals received personal invitations to attend a workshop. These leaders were representative of gender and age, ranging from novices in their mid-twenties with lesser professional/occupational experience, to veteran personnel who had served in consulting/advisory roles in their respective disciplines. The common quality of attendees in all three groups was their interest in the mentorship process and in its improvement it in their respective contexts. Thus, by virtue of this predisposition to supporting leadership development in their organizations, we deduced that this pre-selected population was already motivated and willing to engage in these workshops to enhance the mentoring process across Fiji.

\section{Methodology}

We used a mixed methodology approach by incorporating both qualitative and quantitative means (Tashakkori \& Teddlie, 2010) to address the first two research questions, addressing the third question later, with respect to how our findings related to those in the broader research literature. We gathered, analyzed, and triangulated data from the following sources: returned print questionnaires and surveys that we distributed to attendees at two of the workshops; semi-structured individual and focus-group interviews that we conducted with delegates (several of whom we considered to be panels of experts); field-notes of our observations that we kept during all workshop deliberations; and verbatim records of delegates' oral contributions, especially during talanoa (i.e., group conversation or discussion, Halapua, 2008) sessions. Furthermore, the research team shared these data during regular debriefing sessions.

Principles undergirding the methodology. We based our plans for conducting and evaluating the three workshops on prior assumptions-principles derived both from Pacific island cultures/values/epistemologies, and from the broader research literature on effective professional development (e.g., Fullan, 2007; Steiner, 2004). For instance, we ensured that the workshops were facilitative and interactive rather than pedantic or top-down in nature, and we facilitated the interprofessional group of attendees to begin to explore and create a mentorship approach appropriate to the Fijian context (Madraiwiwi, 2006; Ramesh, 2010). Moreover, we planned the sessions to incorporate recognized principles of adult education (Knowles et al., 2005) and motivational learning (Ralph, 1998b). The two Pacific members of our research team were respected by attendees, and these leaders reassured the participants that although two of the four facilitators were not Pacific islanders, they were credible scholars and friends of the two Pacific organizers. Our team believed that this reassurance was important, because Pacific peoples had experienced negative repercussions from earlier colonial influences (Lawson, 2010). Also, over the years, islanders had grown weary of being exploited by external organizations and outside funding agencies claiming to be helping these nations to develop, but who in actuality did little to promote Pacific nations' autonomy and self-determination (Firth, 2006). We wanted to dispel any misperception that we were attempting to impose the AM model to influence their creativity.

We included a variety of workshop- sessions, such as: individual reflection (e.g., "What does mentoring look like for you?), paired discussion (e.g., "Share a story with a partner regarding a powerful mentoring experience you had."), small-group interaction ("What common themes emerged from these stories?” and "What Fijian metaphor best captures these themes of effective mentorship?”),

The current issue and full text archive of this journal is available at http://www.business.brookes.ac.uk/research/areas/coachingandmentoring/ 
and whole-group synthesis (e.g., "In the light of our deliberations, what might an ideal Tongan mentor and protégé look like?" and "What if anything might the Adaptive Mentorship model contribute to this picture?”). In keeping with South Pacific tradition, these workshop sessions were interspersed with planned times for tea (which according to custom actually took the form of full meals), a noon lunch, and on two occasions, a Kava ceremony (Robinson \& Robinson, 2005), where participants sat in a circle and engaged in conversation while drinking a beverage prepared from locally grown kava root. We found not surprisingly that these nutrition and fellowship breaks served as important venues for participant exchange and dialogue.

We built into the workshops an ongoing, reflexive, and iterative dimension, in which participants were invited to respond (and to suggest modifications) to the deliberations. The Canadian researchers presented their AM model and encouraged attendees to assess it to determine if any of its concepts/components had potential to help inform delegates' reflections as they sought to design a Fijian mentorship model. We also designed the workshop to adhere to Pacific Island protocol, in that sessions were opened and closed with a Christian prayer conducted by a minister or church official, a traditional practice in the Pacific that reflected the spiritual values and beliefs of the region (Manu'atu, 2009); and the workshop opening and closing sessions also included formal speeches given by respected educational or governmental leaders who were well known throughout the Pacific region.

The official participation of these leaders accomplished three goals: (a) it established a positive expectation for the mentorship workshop; (b) it honoured the Pacific value of respecting the social norms and cultural practices by acknowledging rank, authority, and social relationships (Vaioleti, 2003); and (c) it granted legitimacy to the input and participation of the Canadian facilitators, as being trustworthy workshop participants willing to offer their knowledge for consideration by the cohorts.

\section{Results}

We present our data analysis by means of: a quantitative summary of the formal workshopevaluation conducted at the conclusion of the first workshop, as displayed in Table 1; a mixed quantitative/qualitative analysis of attendees' written comments from the second workshop regarding their views of the strengths and challenges of potentially adapting the AM model for mentoring teacher candidates in their teaching-practicum located in Fijian schools; and a summary of the qualitative data we extracted from our observations, interviews, and field-notes of the third workshop.

We used these data to address the three research questions identified earlier in this article. With respect to the first two questions, the data shown in Tables 1 and 2, affirmed that: (a) the workshops did meet their objectives, and (b) that the workshop attendees began to formulate conceptualizations of effective mentorship appropriate to the Fijian context, and they did so by considering portions of the AM model we presented.

Regarding the third research question (i.e., comparing attendees' views of effective mentorship with other perspectives), our findings also confirmed that while attendees espoused many of the qualities of effective mentorship previously reported in the related mentorship literature, they also described it in distinctive and unique ways. On the one hand, attendees in all three workshops were nearly unanimous in acknowledging that even though successful mentorship may take a variety of forms, these various approaches all tend to share common characteristics, namely: they emphasize supportive learning opportunities; they accentuate relational but asymmetrical mutuality; they are developmental by nature

The current issue and full text archive of this journal is available at http://www.business.brookes.ac.uk/research/areas/coachingandmentoring/ 
with definite beginning and end points; and they expect that protégés and mentors will interact in principled and virtuous ways (Allen \& Eby, 2007; Burkehardt, 2012; Johansson-Fua, Sanga, Walker, \& Ralph, 2011; Rose Ragins \& Kram, 2007).

After collating and analyzing all these data regarding the three research questions, we also wrote official technical/accountability reports for the sponsoring agencies (e.g., Sanga, Ralph, \& Walker, 2011; Sanga, Ruru, Walker, \& Ralph, 2011), which described details of the workshops and their results. We summarize our findings below.

\section{Workshop 1}

With respect to the findings from the first workshop, the survey data shown in Table 1 synthesized the perceptions of the $94 \%$ of attendees who completed and returned print surveys.

A second data-source from Workshop 1was our summary of the open comments written by 28 (85\%) of the 33 attendees who submitted evaluation forms. Four key categories emerged from these data, which we italicize and illustrate with sample verbatim comments, below.

The workshop was beneficial/worthwhile (57\% of the written comments):

It has boosted me so much; I will treasure and value this knowledge; It was educational and enjoyable; Informative and fruitful; It helped me visualize what to do back at my school; It has highly equipped me; Looking forward to more high-powered workshops.

More time/discussion was needed for the sessions (46\% of the comments):

The 2 days were not enough; Sometimes the sessions were rushed; $1 \frac{1}{2}$ days is not enough; Time was a restraining factor; Longer to cater to more appropriate discussion; We needed more discussion and clarification.

More workshops and attendees are needed in the future (25\% of the comments):

Another AM workshop next year will help immensely;

More such workshops conducted around Fiji to involve more people;

If we had good mentors nationally, then civil unrest in the region would have been minimized.

Better facilities are needed for the sessions (3\%):

We needed more room and space;

Supply felt pens and newsprint for groups' comments.

The current issue and full text archive of this journal is available at http://www.business.brookes.ac.uk/research/areas/coachingandmentoring/

International Journal of Evidence Based Coaching and Mentoring Vol. 11, No. 2, August 2013 
Table 1: Evaluation Results of Fiji Adaptive Mentorship Workshop 1.

\begin{tabular}{|c|c|c|c|c|}
\hline & \multicolumn{4}{|c|}{ Percentage } \\
\hline Workshop Objectives & $\begin{array}{c}\text { Strongly } \\
\text { Agree }\end{array}$ & Agree & Neutral & Disagree \\
\hline $\begin{array}{l}\text { The workshop helped me to share needs, } \\
\text { challenges, and experiences of mentoring in } \\
\text { organisational, community and societal contexts. }\end{array}$ & 76 & 24 & & \\
\hline $\begin{array}{l}\text { The workshop helped me to understand } \\
\text { mentoring generally and Adaptive Mentorship } \\
\text { (AM) more specifically. }\end{array}$ & 79 & 21 & & \\
\hline $\begin{array}{l}\text { The workshop was effective in helping me with } \\
\text { how to implement Adaptive Mentorship in my } \\
\text { organisational and community contexts. }\end{array}$ & 70 & 27 & 3 & \\
\hline $\begin{array}{l}\text { The workshop provided opportunities to for me to } \\
\text { develop and discuss personal application plans of } \\
\text { AM in my contexts. }\end{array}$ & 73 & 21 & 3 & 3 \\
\hline \multicolumn{5}{|l|}{ Workshop Terminology \& Concepts } \\
\hline $\begin{array}{l}\text { Key terminology, concepts and frameworks were } \\
\text { clarified. }\end{array}$ & 66 & 33 & 2 & \\
\hline \multicolumn{5}{|l|}{ Workshop Sessions } \\
\hline The presentations were engaging and educative. & 87 & 12 & & \\
\hline The sessions were facilitated well. & 90 & 9 & & \\
\hline \multicolumn{5}{|l|}{ Workshop Content and Subject Matter } \\
\hline $\begin{array}{l}\text { The workshop stimulated my interest in } \\
\text { mentoring. }\end{array}$ & 97 & 3 & & \\
\hline I value highly what I learned at the workshop. & 90 & 9 & & \\
\hline Overall Rating & Excellent & Very Good & & \\
\hline $\begin{array}{l}\text { Overall, I would rate the value of the workshop } \\
\text { as: }\end{array}$ & 79 & 21 & & \\
\hline Recommendation & Yes & No & & \\
\hline I would recommend the workshop to others. & 100 & 0 & & \\
\hline
\end{tabular}

\section{Workshop 2}

In Table 2, we summarize our analysis of the written comments submitted by the eight teacher educators from Corpus Christie Teachers College, regarding their assessment of the potential of adapting the AM model in mentoring student teachers during their practicum or internship experiences in actual school settings.

The current issue and full text archive of this journal is available at http://www.business.brookes.ac.uk/research/areas/coachingandmentoring/

International Journal of Evidence Based Coaching and Mentoring Vol. 11, No. 2, August 2013 
Table 2: Respondents' Perceptions of Potential Positive and Limiting Aspects of Using the Adaptive Mentorship Model with Practicum Students, Fiji Workshop 2.

\begin{tabular}{|l|c|}
\hline \multicolumn{1}{|c|}{ Positive Aspects ${ }^{\text {a }}$} & Percentage \\
\hline AM helped me clarify/conceptualize the entire mentoring process. & 44 \\
\hline AM helped me understand protégés' developmental stages & 13 \\
\hline AM confirmed that my intuitive actions were acceptable & 13 \\
\hline AM helped mentors understand/plan their responses/reactions & 4 \\
\hline \multicolumn{1}{|c|}{ Challenging Aspects } & \\
\hline Insufficient time limited the workshop impact. & 17 \\
\hline Needed to implement the model in actual practice. & 9 \\
\hline
\end{tabular}

Note. The return rate was $100 \%$ (8 of 8 delegates).

a $76 \%$ of all submitted comments identified positive features of the AM model.

b $24 \%$ of all submitted comments identified challenging aspects of the AM model.

\section{Workshop 3}

We gathered qualitative data by recording field-notes of our observations of the deliberations and the conversations/interviews with attendees during the full-day event. Our data collection and analysis were guided by the first two research questions, and we summarize our findings, here. As was the case in the first two workshops, the attendees who offered oral comments during the whole-group sessions in Workshop 3 were also complementary in their overall evaluation of the workshop, in that they expressed satisfaction that the key objective had been achieved. They achieved their goal of engaging in serious deliberations regarding the development of a Fijian mentorship approach.

We also noted, as was the case in the earlier workshops, that the Workshop 3 cohort similarly identified strengths and challenges of the AM model. During the talanoa, speakers acknowledged the value of the AM model, as illustrated by one delegate who said, "The AM model has enabled us people in the Pacific to position/contextualize the situation of the mentee and the mentor, and to identify where to work from (from the mentee's developmental level to the mentor's Adaptive response) in the mentoring relationship." Similar comments were: "The model has enabled me to see and analyze where the protégé is at in their stage of development;" and "AM could be used in many different contexts."

Attendees presented additional perceptions that revealed how they adapted the basic principles of the AM model to fit the Fijian context. Examples of these ideas that reflected their cultural beliefs are shown below:

There is the assumption [with AM] that the communication is already taking place between mentor and protégé; but in many cases it is not so. Therefore, the mentor doesn't know where the mentee is at, nor does the mentee know how to work with the mentor.

There is a vacuum in the communication links, and many Pacific people are culturally silent. There is a challenge in the way they can deal with established structures of age and gender.

There is difficulty in Pacific settings to question older leaders, but it varies in different settings, for example, in the traditional villages, or in the professional or work setting.

The current issue and full text archive of this journal is available at http://www.business.brookes.ac.uk/research/areas/coachingandmentoring/

International Journal of Evidence Based Coaching and Mentoring Vol. 11, No. 2, August 2013 
Women cannot go out freely and show leadership in their rural villages. They will need to make use of other existing networks to work with women and girls to avoid gender barriers when trying to take on leadership.

\section{Summary of Findings}

The findings of our study indicated that, in general terms, the three initial research questions were addressed. First, nearly all attendees agreed that the workshop objective had been achieved, namely, that they had begun to explore a cross-disciplinary mentorship approach unique to the Fijian context. Likewise, the second research question (i.e., participants creating an emerging view of mentorship) and the third (i.e., comparing their approach to existing models) had begun to be answered. Evidence was that participants in all three workshops quickly and unreservedly began envisioning what a Fijian mentoring model would look like: (a) by circumspectly incorporating certain elements of the Adaptive Mentorship framework that resonated with their cultural background and experiences (e.g., mentors adjusting their degree of mentoring support and directiveness according to protégés' changing developmental level); (b) by deliberately utilizing Pacific and Fijian metaphors to help describe their approach to effective mentorship (Johansson-Fua, Ruru, Sanga, Walker, \& Ralph, in press); and (c) respectfully but decisively rejecting or ignoring those portions of outside schemes that did not fit their unique setting (Sanga, 2009).

In more specific terms, we summarise key findings that emerged from the three workshops, and we address the third research question by relating the results to those reported in the pertinent literature. First, we re-confirmed both what the literature (e.g., Blanchard, 2010; Fullan, 2007; Steiner, 2004) and what individuals' workplace experiences have shown regarding core principles that undergird effective professional-development initiatives, almost universally. These principles are that: (a) the issues addressed in professional development should be relevant and meaningful to participants; (b) any type of professional development program should simultaneously enhance both individual and institutional effectiveness; (c) the event should actively engage participants in useful/practical learning opportunities; (d) it should promote networking and reflection among the community-members; and (e) it should provide participants with sufficient time and resources to achieve the project goals. Our analysis has shown that these five criteria were generally achieved in the Fijian workshops.

A second specific finding was that there was a distinction made between facilitating and directing the groups in their processing of the ideas generated regarding effective mentorship for Fiji. We had anticipated correctly that a transmission approach would have been unacceptable to attendees. Thus, we ensured that our workshop design involved a transaction approach with plenty of face-to-face interaction and collaboration, which also generated intensity and emotion among participants advocating their respective positions. We noted that in all three workshops participants engaged in serious discussion/debate regarding the philosophical underpinnings of mentorship in the Fijian context (Johansson-Fua, Ruru, Sanga, Walker, \& Ralph, in press), and they did agree that creating an adaptable mentorship approach was possible.

A third specific finding was that participants' comments registered the existence of a certain level of trust, which permeated the deliberations in all three venues, despite the divergence of individuals' workplaces, disciplinary, and cultural/ethnic (i.e., indigenous-Fijian and Indo-Fijian backgrounds). They had willingly risked accepting our research team's invitation to attend the workshops and to collaborate with fellow Fijian leaders, many of whom they did not previously know. Moreover, their

The current issue and full text archive of this journal is available at http://www.business.brookes.ac.uk/research/areas/coachingandmentoring/ 
willingness to converse candidly with one another and with the workshop leaders and to freely identify limitations and/or raise questions about the usefulness of the AM model all served to validate for us that the attendees had indeed begun the quest of developing a viable mentorship model appropriate for diverse Fijian settings.

\section{Limitations and Implications}

The main limitation identified by attendees and facilitators alike, was the lack of time, either to become adequately acquainted with the AM model (in the case of Workshop 2), or to finish creating a preliminary prototype of a mentorship approach adaptable to Fijian society (as in Workshops 1 and 3). All participants recognized that sufficient time/resources were required to continue this work. This dissatisfaction with time constraints mentioned by several attendees was summarized by one attendee who wrote, "Sometimes the sessions were rushed; and time was the restraining factor. For such an important workshop where our future is at stake, more time should have been allocated for more discussion.”

We further realized that the workshops simultaneously revealed similarities and differences among attendees' conceptualizations and beliefs regarding the process of mentorship, which was the case in other Pacific nations we visited, such as Tonga (Johansson-Fua, Sanga, Walker, \& Ralph, 2011), as well as in the broader mentorship literature (e.g., Allen \& Eby, 2007; Clutterbuck, Poulsen, \& Kochan, in press; Emelo, 2011; Haggard, Dougherty, Turban, \& Wilbanks, 2011). Findings from all these sources indicated that mentorship and coaching are based on a supportive learning relationship between/among individuals; they reflect a mutual but asymmetrical arrangement; they are changeable over time and context; they are variable in terms of definition, structure, and procedure; they may be conducted both formally and informally; and they may not function without interpersonal problems.

Another observation we made during the workshop experiences was that the participants were not preoccupied with or distracted by the uncertain political situation that had (and still) existed in Fiji, but rather that they focused on the goal of investigating successful mentorship and leadership practice as one viable solution to many of the prevailing social and economic difficulties in Fiji. We further observed that this diligence that the cohorts demonstrated in adapting mentorship to improve their occupational and educational lives reflected a parallel process, which has been described in research from other parts of the world (Schleicher, 2009).

To us, as the workshop facilitators, the planning and delivery of the entire week's mentoringworkshop program in Fiji corroborated previous research results from larger-scale institutional reforms (Fullan, 2007; Kezar \& Eckel, 2002), including those reported in other Pacific island nations (e.g., Taufe'ulungaki, 2009). All these studies revealed that effective change initiatives have certain commonalities, such as: (a) senior administrative support from several organizations is evident, (b) collaborative leadership is instrumental in enacting the initiative; (c) careful program design and a tangible vision are prominent; (d) staff/protégé development initiatives are provided; (e) multiple layers of culture/history are considered; (f) proposed strategies are aligned with the local culture; and (g) follow-up action is planned and visible. We observed the first six of these characteristics within the Fijian mentorship workshops, although the last item (i.e., follow-up) had not yet been realized at the time of writing this article.

The current issue and full text archive of this journal is available at http://www.business.brookes.ac.uk/research/areas/coachingandmentoring/ 


\section{Concluding Thoughts}

We noted that workshop participants did not view the AM model as a panacea to resolve leadership difficulties that existed across the variety of domains represented, but rather that they saw it as: (a) a way to clarify their generic conceptualization of the mentoring process as a whole, and (b) a means of helping to focus mentors' behavior by suggesting how to match mentor response in inverse proportions to the protégés' existing levels of task-specific competence and confidence. Several attendees from a variety of disciplinary settings and professional contexts mentioned the usefulness of this adaptive process.

We were honoured to be invited to facilitate the mentorship workshops in Fiji, and we observed that the participants seemed to genuinely engage in this cross-disciplinary and pan-Fijian initiative. The two Canadian facilitators of our team were pleased that participants considered, examined, and evaluated the AM model, in terms of how it could help inform the creation of their own mentorship model. We observed that a spirit of trust appeared to be present among the attendees and facilitators, which was due in no small part to the influence of our two Pacific team-members, whose own past credibility as respected mentors, themselves, no doubt helped prevent potential suspicions from arising with respect to forcing outside ideas on attendees On the contrary, the three cohorts were able to distinguish among the components of the AM model that they discerned had greater or lesser applicability to their contexts. In fact, one respondent stated on the evaluation form:

I think that a mentorship model of this type should be nationally implemented. If we had had good mentors, civil unrest in the region would have been minimized, and the "Pacific Way of Life" could have been an example to the whole world. I strongly believe that if there was a model for people in the region to follow, then it would be practicable.

We, the authors, share this participant's view that ongoing cross-cultural, collaborative efforts would help sustain the impetus that was evident among the participants who began the process of developing a Fijian mentorship model.

\section{What We Learned}

The preliminary conclusions we derived from our analysis of the three Fijian mentorship workshops corroborated those we reached both in the concurrent mentorship research in the kingdom island of Tonga (Johansson-Fua, Ruru, Sanga, Walker \& Ralph, in press; Johansson-Fua, Sanga, Walker, \& Ralph, 2011) and in the broader research-literature on international leadership, mentoring, and coaching (Clutterbuck, Poulsen, \& Kochan, in press; Fullan, 2007; Outer den, 2010; Passmore, 2009). Following is a synthesis of five principles we extracted from these three research sources:

- There appears to be a sincere willingness among leaders across the South Pacific region to collaborate both regionally and internationally, with the goal of developing and/or enhancing the leadership and mentorship process regardless of the professional and occupational disciplines they represented.

- Although these leaders' view of "effective mentorship/coaching” reflected the generic qualities and principles identified in contemporary research-literature, they insisted that useful mentorship approaches must be adapted to local/regional customs, traditions, and cultures.

The current issue and full text archive of this journal is available at http://www.business.brookes.ac.uk/research/areas/coachingandmentoring/

International Journal of Evidence Based Coaching and Mentoring Vol. 11, No. 2, August 2013 
- Leaders attending the series of workshops we conducted across the Pacific region appeared to view the Adaptive Mentorship model we presented not as an external approach to be blindly adopted, but rather as a conceptual framework with components that could be adapted within their respective training and workplace settings. Attendees affirmed the AM model's emphasis on mentors adjusting their responses to meet the individual developmental needs of protégés; but the attendees preferred expressing this adaptive aspect using contextually created metaphors, which they deemed more appropriate to the Pacific environment than the AM model's current structure.

- We interpreted the attendees' guarded acceptance of the adaptive aspect of the AM model as evidence of successful achievement of our research objectives. However, we believe that this success would not have been achieved without the credibility of the Pacific members of our research team who supported the adaptation of AM.

- Our investigation of mentorship in the Pacific region is one part of a growing research thrust examining the complexities of leadership/mentoring/coaching as socially constructed processes that not only function within specific cultures, but that are also often being increasingly organized and/or coordinated by cross-cultural and inter-professional teams. We saw glimpses of what Joanna Kidman (2012) described as “...the emergence of a new kind of leadership in the Pacific that is not only conversant with a range of cultural contexts but also able to move freely between them on its own terms” (p. 227). We affirm her description, and therefore encourage interested practitioners and scholars to capitalize on this current momentum by continuing to pursue efforts to develop mentoring and coaching frameworks that not only fit specific cultural contexts, but that also permit participants “...to move fluidly between cultures” (p. 227).

\section{References}

Abedin, Z., Biskup, E., Silet, K., Garbutt, J., Kroenke, K., Feldman, M., et al. (2012). Deriving competencies for mentors of clinical and translational scholars. Clinical and Translational Science. 5(3): 273-80.

Bachkirova, T., Jackson, P. \& Clutterbuck, D. (2011). Coaching and mentoring supervision: Theory and practice. Maidenhead, Berkshire, UK: Open University Press McGraw-Hill.

BBC News Online. (2011, February 9). Fiji country profile. Retrieved $4^{\text {th }}$ February 2012 from http://news.bbc.co.uk/2/hi/asia-pacific/country_profiles/1300477.stm

BBC News Online. (2006, December 8). Background to Fiji's four coups. Retrieved 14th January 2012 from http://news.bbc.co.uk/2/hi/asia-pacific/6209486.stm

Allen, T., \& Eby, L. (Eds). (2007). The Blackwell handbook of mentoring: A multiple perspective approach. Malden, MA: Blackwell.

Blanchard, K. (Ed.). (2010). Leading at a higher level. Upper Saddle River, NJ: FT Press and Blanchard Management Corporation.

Bozeman, B., \& Feeney, M. (2007). Toward a useful theory of mentoring: a conceptual analysis and critique. Administration \& Society, 39, 719-739. Retrieved $4^{\text {th }}$ February 2012 from http://aas.sagepub.com/content/39/6/719

The current issue and full text archive of this journal is available at http://www.business.brookes.ac.uk/research/areas/coachingandmentoring/ 
Brock, V. (2011). Secret history of coaching. International Journal of Mentoring and Coaching, 9(1). Retrieved $4^{\text {th }}$ February 2012 from: http://www.emccouncil.org/eu/en/e-journal/e-journal extract

Burkhardt, K. (2012). Mentoring: Are seasoned nurses doing their best? Nurse Together.com. Retrieved $8^{\text {th }}$ November 2012 from: http://www.nursetogether.com/Career/CareerArticle/VersionId/36686/modid/599.aspx

Carnegie Foundation for the Advancement of Teaching. (2011). Professional and graduate education: Preparation for the professions program (PPP: Clergy study, Engineering study, Law study, Medical education study, Nursing study, Teacher education study). Retrieved $5^{\text {th }}$ January 2012 from http://www.carnegiefoundation.org/previous-work/professional-graduate-education

Chang, B., Munoz, D., Donoff, R., Kinnunen, T., \& Wright, R. (2012). A 10-year survey of US deans: Trends, challenges, and mentoring in prosthodontics, part 2. Journal of Prosthodontics, 21(1), 6572. Retrieved $4^{\text {th }}$ February 2012 from http://onlinelibrary.wiley.com/doi/10.1111/j.1532849X.2011.00757.x/pdf

Chaudhary, F. (2011a, September 03). Keep your word, leaders urge Fiji. Fiji Times Online Newspaper. Retrieved $4^{\text {th }}$ February 2012 from http://www.fijitimes.com/story.aspx?id=179546

Chaudhary, F. (2011b, September 03). Ministers endorse plan for return to democracy. Fiji Times Online Newspaper. Retrieved $4^{\text {th }}$ February 2012 from: http://www.fijitimes.com/story.aspx?id=179545

Chrosniak, P., Ralph, E., \& Walker, K. (2013). What role can questioning play in mentorship? The Mentor.

Chu, C. (2009). Mentoring for leadership in Pacific education (Doctoral dissertation). Victoria University of Wellington, Wellington, NZ. Retrieved $20^{\text {th }}$ January 2012 from: http://researcharchive.vuw.ac.nz/bitstream/handle/10063/1103/thesis.pdf?sequence=1

Chun, J. U., Sosik, J. J., \& Yun, N. Y. (2012). A longitudinal study of mentor and protégé outcomes in formal mentoring relationships. Journal of Organizational Behavior, 33, 1071-1094.

Clutterbuck, D. (2008). What's happening in coaching and mentoring? And what is the difference between them? Development and Learning in Organisations, 22(4), 8-10.

Clutterbuck, D., Poulsen, K., \& Kochan, F. (Eds.). (2012). Developing successful diversity mentoring programmes: An international casebook. New York: Open University Press.

Brefi Group Limited. (2011). Coaching and mentoring-the difference. Retrieved $18^{\text {th }}$ December 2012 from http://www.brefigroup.co.uk/coaching/coaching_and_mentoring.html

Coates, W. (2012). Being a mentor: What's in it for me? Academic Emergency Medicine, 19(1), 92-97. Retrieved $14^{\text {th }}$ January 2012 from: http://onlinelibrary.wiley.com/doi/10.1111/j.15532712.2011.01258.x/abstract

Colvin, M., \& Francis, A. (2011, September 2). Protest against deteriorating Fijian human rights. Report on Australian Broadcasting Cooperation, ABC.net.au. Retrieved $4^{\text {th }}$ February 2012 from http://www.abc.net.au/pm/content/2011/s3308940.htm

The current issue and full text archive of this journal is available at http://www.business.brookes.ac.uk/research/areas/coachingandmentoring/

International Journal of Evidence Based Coaching and Mentoring Vol. 11, No. 2, August 2013 
Dunphy, A., Gavin, B., Solomon, F., Stewart, C., Collins, E., \& Grant, A. (2008). Guide to effective practice in youth mentoring, New Zealand. Auckland, NZ: Youth Mentoring Network. Retrieved $12^{\text {th }}$ November 2012 from: http://www.youthmentoring.org.nz/content/docs/GYM.1.pdf

EEO Trust. (2011, November). Specifically Pacific: Engaging young Pacific workers (Report). Auckland, New Zealand: Equal Employment Opportunities Trust, Ministry of Social Development, Government of New Zealand. Retrieved $12^{\text {th }}$ November 2012 from: http://www.eeotrust.org.nz/content/docs/reports/Specifically\%20Pacific\%20Report.pdf

Emelo, R. (2011, June). Conversations with mentoring leaders. $T$ \& D (Training \& Development) Journal. Retrieved $4^{\text {th }}$ February 2012 from: http://www.3creek.com/research/Conversations_with_Mentoring_Leaders_T+D_Jun11.pdf

Fraenkel J., \& Firth, S. (Eds). (2007). From election to coup in Fiji: The 2006 campaign and its aftermath. Canberra, Australia: Co-Published by the Australian National University, ANU E Press and Asia Pacific Press. Retrieved $4^{\text {th }}$ February 2012 from: http://epress.anu.edu.au/fiji_citation.html

Fereday, J., \& Muir-Cochrane, E. (2006). Demonstrating rigor using thematic analysis: A hybrid approach of inductive and deductive coding and theme development. International Journal of Qualitative Methods 2006, 5(1), 80-92. Retrieved 29 ${ }^{\text {th }}$ November 2012 from: http://ejournals.library.ualberta.ca/index.php/IJQM/article/view/4411/3530

Firth, S. (Ed.), (2006). Globalisation and governance in the Pacific islands. Canberra, Australia: The Australian National University, ANU E Press.

Fullan, M. (2007). The new meaning of educational change (4th ed.). New York: Teachers College.

Gundling, E., Hogan, T., \& Cvitkovich, K. (2011). 10 key behaviors that define great global leaders. Boston: Nicholas Brealey.

Haggard, D., Dougherty, T., Turban, D., \& Wilbanks, J. (2011). Who is a mentor? A review of evolving definitions and implications for research. Journal of Management, 37(1), 280-304. Retrieved $4^{\text {th }}$ March 2012 from http://jom.sagepub.com/content/37/1/280.full.pdf+html

Halapua, W. (2008). Moana methodology: A way of promoting dynamic leadership. Talanoa Oceania. Retrieved $4^{\text {th }}$ February 2012 from: https://sites.google.com/a/nomoa.com/talanoa/Home/paperspresentations/halapua--moana

Hannan, K. (2006). Fiji: Sugar and sweatshirts, migrants and remittances. In S. Firth (Ed.), Globalisation and governance in the Pacific islands (pp. 189-215). Canberra, Australia: The Australian National University, ANU E Press. Retrieved 6 ${ }^{\text {th }}$ March 2012 from: http://epress.anu.edu.au/ssgm/global_gov/pdf/ch10.pdf

Hooper, A. (Ed.). (2005). Culture and sustainable development in the Pacific. Canberra, Australia: Copublished by The Australian National University, ANU E Press and Asia Pacific Press. Retrieved $6^{\text {th }}$ March 2012 from http://epress.anu.edu.au/culture_sustainable/prelims.pdf

Hutchings, P., Taylor Huber, M., \& Ciccone, A. (2011). The scholarship of teaching and learning reconsidered: Institutional integration and impact. San Francisco: Jossey-Bass.

The current issue and full text archive of this journal is available at http://www.business.brookes.ac.uk/research/areas/coachingandmentoring/

International Journal of Evidence Based Coaching and Mentoring Vol. 11, No. 2, August 2013 
International Coach Federation. (2012). Global coaching study -Executive summary. Retrieved $15^{\text {th }}$ August 2012 from http://coachfederation.org/coachingstudy2012/

Johansson-Fua, S., Ruru, D., Sanga, K., Walker, K., \& Ralph, E. (2013). Creating mentorship metaphors: Pacific island perspectives. Learning Landscapes, 6, 241-259. http://www.learninglandscapes.ca/images/documents/ll-no11.pdf

Johansson-Fua, S., Sanga, K., Walker, K., \& Ralph, E. (2011). Mentorship in the professions: A perspective from Tonga. The International Journal of Mentoring and Coaching, 9(2), 19-37.

Keeney, S., Hasson, F., \& Mckenna, H. (2006). Consulting the oracle: Ten lessons from using the Delphi technique in nursing research. Journal of Advanced Nursing, 53(2), 205-212. Retrieved $29^{\text {th }}$ November 2012 from: http://onlinelibrary.wiley.com/doi/10.1111/j.1365-2648.2006.03716.x/pdf

Kezar, A., \& Eckel, P. (2002). The effect of institutional culture on change strategies in higher education. The Journal of Higher Education, 73, 435-460.

Kidman, J. (2012). A Pacific decade: Some concluding thoughts. In K. Sanga \& J. Kidman (Eds.), Harvesting ideas: Niu generation perspectives (pp. 225-234). Suva, Fiji: USP Press, University of the South Pacific.

Knowles, M., Holton, E., III, \& Swanson, R. (2005). The adult learner: The definitive classic in adult education and human resource development (6th ed.). Burlington, MA: Elsevier.

Koortzen, P., \& Oosthuizen, R. (2010). A competence executive coaching model. A competence executive coaching model. SA Journal of Industrial Psychology/SA Tydskrif vir Bedryfsielkunde, 36(1). Retrieved $18^{\text {th }}$ December 2012 from: http://www.scielo.org.za/pdf/sajip/v36n1/v36n1a11.pdf

Lawson, S. (2010). Post-colonialism, neo-colonialism and the "Pacific way:" A critique of (un)critical approaches [Discussion paper, 2010/4]. Canberra, Australia: State, Society and Governance in Melanesia Program, School of International, Political \& Strategic Studies, ANU College of Asia and the Pacific, The Australian National University. Retrieved $4^{\text {th }}$ February 2012 from: http://ips.cap.anu.edu.au/ssgm/papers/discussion_papers/2010_04_lawson.pdf

Leadership Pacific. (2005). Profile. Retrieved 6 ${ }^{\text {th }}$ March 2012 from: http://www.leadershippacific.org/profile/

Madraiwiwi, R. (2006). Keynote address, Governance in Fiji: The interplay between indigenous tradition, culture and politics. In S. Firth (Ed.), Globalisation and governance in the Pacific islands (pp. 289-296). Canberra, Australia: The Australian National University, ANU E Press. Retrieved $4^{\text {th }}$ February 2012 from: http://epress.anu.edu.au/ssgm/global gov/pdf/ch15.pdf

Manu'atu, L. (2009). Pacific processes and pedagogies. In K. Sanga \& K. Helu-Thaman (Eds.), Rethinking education curricula in the Pacific: Challenges and prospects (pp. 172-182). Wellington, NZ: He Parekereke Institute for Research and Development in Maori and Pacific Education, Victoria University of Wellington.

Mara, D., \& Marsters, M. (October 2009). Pasifika Students: supporting academic success through the provision of mentoring (Report to Ako Aotearoa Regional Hub Project Fund Scheme). Hawke's Bay, New Zealand: Eastern Institute of Technology. Retrieved $12^{\text {th }}$ November 2012 from:

The current issue and full text archive of this journal is available at http://www.business.brookes.ac.uk/research/areas/coachingandmentoring/

International Journal of Evidence Based Coaching and Mentoring Vol. 11, No. 2, August 2013 
http://akoaotearoa.ac.nz/download/ng/file/group-4/n3954-pasifika-students-supporting-academicsuccess-through-the-provision-of-mentoring.pdf

Nabobo-Baba, U. (2009). Fijian epistemology: Examining aspects of Vugalei cultural pedagogies, processes and possible futures. In K. Sanga \& K. Helu-Thaman (Eds.), Re-thinking education curricula in the Pacific: Challenges and prospects (pp. 137-158). Wellington, NZ: He Parekereke Institute for Research and Development in Maori and Pacific Education, Victoria University of Wellington.

Naidu, V. (2006). The state of the state in Fiji: some failings in the periphery. In S. Firth (Ed.), Globalisation and governance in the Pacific islands (pp. 297-315). Canberra, Australia: The Australian National University, ANU E Press. Retrieved $4^{\text {th }}$ February 2012 from: http://epress.anu.edu.au/ssgm/global_gov/pdf/ch16.pdf

Narayan, V. (2011, March 9).11 Pacific countries support Fiji’s roadmap. Report in fijivillage.com. Suva, Fiji Islands: Communications Fiji Limited (CFM). Retrieved $4^{\text {th }}$ February 2012 from: http://www.fijivillage.com/?mod=story\&id=02091145eefdd35eed1ec763b2f2b4

Norton, R. (2005). A paradox of tradition in a modernising society: Chiefs and political development in Fiji. In A. Hooper (Ed.), Culture and sustainable development in the Pacific (pp. 142-158).

Canberra, Australia: Co-published by The Australian National University, ANU E Press and Asia Pacific Press. Retrieved 6 ${ }^{\text {th }}$ March from: http://epress.anu.edu.au/wpcontent/uploads/2011/06/whole book10.pdf

Outer den, B. (2010). Coaching and cross-cultural transitions: A narrative inquiry approach. International Journal of Evidence Based Coaching and Mentoring (Special Issue 4, pp. 95-105). Retrieved $18^{\text {th }}$ December 2012 from: http://business.brookes.ac.uk/commercial/work/iccld/ijebcm/documents/special4-paper-07.pdf

Passmore, J. (Ed.). (2009). Diversity in coaching: Working with gender, culture, race and age. London: Kogan Page.

Puamau, P. (2005). The Fiji-Australia teacher education project at the Fiji College of Advanced Education: Who really benefitted? In K. Sanga, C. Chu, C. Hall, \& L. Crowl (Eds.), Re-thinking aid relationships in Pacific education (pp. 116-127). Wellington, NZ: He Parekereke Institute for Research and Development in Maori and Pacific Education, Victoria University of Wellington; and Suva, Fiji: Institute of Education, University of the South Pacific.

Ralph, E. (1998a). Developing practitioners: A handbook of contextual supervision. Stillwater, OK: New Forums Press.

Ralph, E. (1998b). Motivating teaching in higher education: A manual for faculty development. Stillwater, OK: New Forums Press

Ralph, E. (2005). Enhancing managers' supervisory effectiveness: A promising model. The Journal of Management Development, 24(3), 267-284.

Ralph. E., \& Walker, K. (2010). Enhancing mentors' effectiveness: The promise of the Adaptive Mentorship $@$ model. McGill Journal of Education, 45(2), 205-218. [Lead author.] Retrieved $13^{\text {th }}$ February 2011from http://mje.mcgill.ca/index.php/MJE/article/view/4653

The current issue and full text archive of this journal is available at http://www.business.brookes.ac.uk/research/areas/coachingandmentoring/

International Journal of Evidence Based Coaching and Mentoring Vol. 11, No. 2, August 2013 
Ralph, E., \& Walker, K. (Eds.). (2011a). Adapting mentorship across the professions: Fresh insights \& perspectives. Calgary, Alberta, Canada: Temeron/Detselig Publishers.

Ralph, E., \& Walker, K. (2011b). Enhancing mentoring in management via the Adaptive Mentorship( model. The International Journal of Knowledge, Culture and Change Management, 10(8), 35-43.

Ralph, E., \& Walker, K. (2011c). Helping novices develop in the humanities via Adaptive Mentorship@). The International Journal of the Humanities, 9(2), 121-132.

Ralph, E., \& Walker, K. (2012a). Enhancing mentoring across the disciplines: Via the Adaptive Mentorship model. Bridges: Reflecting the scholarship of teaching \& learning at the University of Saskatchewan, 10(3), 9-11.

Ralph, E., \& Walker, K. (2012b). Enhancing rural internships: Considering the post-intern voice. Northwest Passage: Journal of Educational Practices, 10(1), 36-44.

Ralph, E., \& Walker, K. (2013). The promise of Adaptive Mentorship: What is the evidence? International Journal of Higher Education 2(2), pp.76-85.

Ralph, E., \& Walker, K. (in press). Internships in rural schools: Post-interns' views. Journal of Cooperative Education and Internships.

Ramesh, S. (2010). History of inter-group conflict and violence in modern Fiji. Sydney, Australia: University of Sydney, Centre for Peace and Conflict Studies. Retrieved $4^{\text {th }}$ February 2012 from: http://www.observatori.org/paises/pais_52/documentos/SK-Ramesh-2010-thesis.pdf

Robinson D., \& Robinson, K. (2005). Pacific ways of talk: Hui and talanoa. Wellington, New Zealand: Social and Civic Policy Institute; and Dayton, $\mathrm{OH}$ : Council on Public Policy Education. Retrieved $6^{\text {th }}$ March 2012 from http://scpi.org.nz/scpi_docs/Pacific_Ways_of_Talk.pdf

Rolfe, G. (2006). Validity, trustworthiness and rigour: Quality and the idea of qualitative research. Journal of Advanced Nursing, 53(3), 304-310. Retrieved $29^{\text {th }}$ November 2012 from: http://web.ebscohost.com/ehost/pdfviewer/pdfviewer?sid=f071ad0b-8641-4213-a9840d048459e96e\%40sessionmgr11\&vid=2\&hid=11

Rombeau, J., Goldberg, A., \& Loveland-Jones, C. (2010). Surgical mentoring: Building tomorrow's leaders. New York, NY: Springer. Retrieved $4^{\text {th }}$ February 2012 from: http://jama.amaassn.org/content/305/4/410.extract

Rose Ragins, B., \& Kram, K. (Eds). (2007). The handbook of mentoring at work: Theory, research, and practice. Los Angeles, CA: Sage.

Ruru, D. (2009).Tovolea, tovolea, ko na qai rawata: Try and try and you will achieve. In K. Sanga \& C. Chu (Eds.), Living and leaving a legacy of hope: Stories by new generation Pacific leaders (pp. 164-168). Wellington, NZ: He Parekereke Institute for Research and Development in Maori and Pacific Education, Victoria University of Wellington.

Sambunjak, D., Straus, S., \& Marusic, A. (2006). Mentoring in academic medicine: A systematic review. Journal of the American Medical Association, 269(9), 1103-1115. Retrieved $14^{\text {th }}$ February 2012 from http://jama.ama-assn.org/content/296/9/1103.full.pdf+html

The current issue and full text archive of this journal is available at http://www.business.brookes.ac.uk/research/areas/coachingandmentoring/

International Journal of Evidence Based Coaching and Mentoring Vol. 11, No. 2, August 2013 
Sanga, K. (2005). A strategy for rethinking aid relationships. In K. Sanga, C. Chu, C. Hall, \& L. Crowl (Eds.), Re-thinking aid relationships in Pacific education (pp. 11-27). Wellington, NZ: He Parekereke Institute for Research and Development in Maori and Pacific Education, Victoria University of Wellington; and Suva, Fiji: Institute of Education, University of the South Pacific.

Sanga, K. (2009). Curriculum as process: Essential phases and features of Ausae pedagogy. In K. Sanga \& K. Helu-Thaman (Eds.), Re-thinking education curricula in the Pacific: Challenges and prospects (pp. 222-236). Wellington, NZ: He Parekereke Institute for Research and Development in Maori and Pacific Education, Victoria University of Wellington.

Sanga, K., \& Chu, C. (Eds.). (2009). Living and leaving as legacy of hope: Stories by new generation Pacific leaders. Wellington, NZ: He Parekereke Institute for Research and Development in Maori and Pacific Education, Victoria University of Wellington.

Sanga, K., Ralph, E., \& Walker, K. (2011). Report on the Suva adaptive mentorship workshop (28 pp.). Te Kura Maori, Faculty of Education, Victoria University of Wellington, Wellington, NZ.

Sanga, K., Ruru, D., Walker, K., \& Ralph, E. (2011). Report on the Lautoka adaptive mentorship workshop (39 pp.). Te Kura Maori, Faculty of Education, Victoria University of Wellington, Wellington, NZ.

Sanga, K., Tagivakatini, S., \& Johansson-Fua, S. (Eds.). (2008, May). Rethinking the rethinking of Pacific education initiative. Report of the Pacific Regional Symposium to the Re-thinking Pacific Education Initiative for \& by Pacific Peoples (RPEIPP) \& New Zealand International Aid \& Development Agency (NZAID) conducted at the University of the South Pacific, Suva, Fiji.

Schleicher, A. (2009). International benchmarking as a lever for policy reform. In A. Hargreaves \& M. Fullan (Eds.), Change wars (pp. 97-115). Bloomington, IN: Solution Tree.

Schreuder, H., Wolswijk, R., Zweemer, R., Schijven, M., \& Verheijen, R. (2012). Training and learning robotic surgery, time for a more structured approach: A systematic review. BJOG: An

International Journal of Obstetrics and Gynaecology, 119(2), 137-149. Retrieved $6^{\text {th }}$ March 2012 from http://onlinelibrary.wiley.com/doi/10.1111/j.1471-0528.2011.03139.x/ful l

Selby, R., \& Walsh-Tapiata, W. (2005). Reflections on teaching and learning in Fiji. In K. Sanga, C. Chu, C. Hall, \& L. Crowl (Eds.), Re-thinking aid relationships in Pacific education (pp. 251260). Wellington, NZ: He Parekereke Institute for Research and Development in Maori and Pacific Education, Victoria University of Wellington; and Suva, Fiji: Institute of Education, University of the South Pacific.

Stanulis, R., Little, S., \& Wibbens, E. (2012). Intensive mentoring that contributes to change in beginning elementary teachers' learning to lead classroom discussions. Teaching and Teacher Education, 28(1), 32-43. Retrieved $20^{\text {th }}$ February 2012 from http://www.sciencedirect.com/science/article/pii/S0742051X11001016

Steiner, L. (2004). Developing effective professional development experiences: What do we know? Naperville, IL: Learning Point Associates and The John Edward Professional Development Center. Retrieved $4^{\text {th }}$ February 2012 from:

http://www.tqsource.org/issueforums/plantoAction/resources/4_PDResearchPolicyAction/Design ingEffectivePD.pdf

The current issue and full text archive of this journal is available at http://www.business.brookes.ac.uk/research/areas/coachingandmentoring/

International Journal of Evidence Based Coaching and Mentoring Vol. 11, No. 2, August 2013 
Tashakkori, A., \& Teddlie, C. (2010). Sage handbook of mixed methods in social \& behavioural research (2nd ed.). Thousand Oaks, CA: Sage.

Taufe'ulungaki, A. (2009). Tongan values in education: Some issues and questions. In K. Sanga \& K. Helu-Thaman (Eds.), Rethinking education in the Pacific: Challenges and prospects (pp. 125136). Wellington, NZ: He Parekereke Institute for Research and Development in Maori and Pacific Education, Victoria University of Wellington.

Thaman, K. (2006). Acknowledging indigenous knowledge systems in higher education in the Pacific island region. In L. Meek \& C. Sawanwela (Eds.), Higher education, research and knowledge in the Asia-Pacific region (pp. 175-184). New York: Palgrave.

Thaman, K. (2009). Introduction: the need to rethink Pacific education. In K. Sanga \& K. Helu-Thaman (Eds.), Rethinking education in the Pacific: Challenges and prospects (pp. 13-27). Wellington, NZ: He Parekereke Institute for Research and Development in Maori and Pacific Education, Victoria University of Wellington.

United States Department of State. (2012, February 15). Background note: Fiji. Bureau of East Asian and Pacific Affairs, Author. Retrieved $4^{\text {th }}$ March 2012 from http://www.state.gov/r/pa/ei/bgn/1834.htm

Vaioleti, T. (2003). Talanoa research methodology: A developing position on Pacific research. Pacific research in education interest group Pasifika symposium 2003 [Collection of Papers, pp. 28-35]. Hamilton, NZ: Wilf Malcolm Institute for Educational Research, University of Waikato.

Veitayaki, J. (2005). Fisheries resource-use culture in Fiji and its implications. In A. Hooper (Ed.), Culture and sustainable development in the Pacific (pp. 116-130). Canberra, Australia: Copublished by The Australian National University, ANU E Press and Asia Pacific Press. Retrieved $24^{\text {th }}$ February 2012 from http://epress.anu.edu.au/culture_sustainable/ch09.pdf

Ward, D., \& Wu, C. (2012). Don't forget mentoring. Anaesthesia, 67(2), 186-187. Retrieved $16^{\text {th }}$ May 2012 from http://onlinelibrary.wiley.com/doi/10.1111/j.1365-2044.2011.07031.x/full

Wasburn, M., Wasburn-Moses, L., \& Davis, D. (2012). Mentoring special educators: The roles of national board certified teachers. Remedial and Special Education, 33(1), 59-66. Retrieved 24 ${ }^{\text {th }}$ June 2012 from http://rse.sagepub.com/content/33/1/59

Wheeler, M., Keller, T., \& Dubois, D. (2010). Review of three recent randomized trials of school-based mentoring: Making sense of mixed findings. Sharing Child and Youth Development Knowledge, 24(3). Retrieved $24^{\text {th }}$ February 2012 from: http://www.mentoring.research.pdx.edu/index.php?option=com content\&view=article\&id=17\&It emid $=13$

Wheeler, C., \& Leftwich, A. (2012). Leadership coalitions in the Pacific: The Tonga initiative. Policy and Practice for Developmental Leaders, Elites and Coalitions: Coalitions in the Politics of Development: Findings, insights and guidance from the DLP Coalitions, A Research and Policy Workshop Report (pp. 33-34). DLP Developmental Leadership Program Workshop, Sydney, 15-16 February 2012. Auasaid, Government of Australia. Retrieved November $12^{\text {th }} 2012$ from: http://www.dlprog.org/ftp/view/Public\%20Folder/Coalitions\%20in\%20the\%20Politics\%20of\%20D evelopment.pdf

The current issue and full text archive of this journal is available at http://www.business.brookes.ac.uk/research/areas/coachingandmentoring/ 
Wiersma, W., \& Jurs, S. (2008). Research methods in education: An introduction (9 $9^{\text {th }}$ ed.). New York: Pearson.

Willens, J. (2012). Editorial: Make mentoring one of your professional career goals. Pain Management Nursing, 13(1), 1. Retrieved $6^{\text {th }}$ July 2012 from: http://www.sciencedirect.com/science/article/pii/S1524904211002311

Yoo, In-Sung. (2004, February 3). Education: mentoring swells into “a movement.” USA Today. Retrieved 20 $0^{\text {th }}$ May 2012 from: http://www.usatoday.com/news/education/2004-01-26mentoring_x.htm

Donasiano Ruru was born in Fiji, where he is currently a teacher educator at the University of the South Pacific. He has a PhD from Victoria University of Wellington.

Kabini Sanga is an Associate Professor in the Faculty of Education, Karori Campus at Victoria University of Wellington, and is a key educational leader across the South Pacific.

Keith Walker is a Professor in the Department of Educational Administration and the Johnson Shoyama Graduate School of Public Policy at the University of Saskatchewan in Saskatoon, Canada.

Edwin Ralph is a Professor and Facilitator/Supervisor of Extended Practicum with the Department of Curriculum Studies, College of Education, at the University of Saskatchewan in Saskatoon, Canada. 